\title{
Scenes of Language Violence in Yolanda Oreamuno's La ruta de su evasión
}

La novela La ruta de su evasión (1948), de la autora costarricense Yolanda Oreamuno, representa prácticas públicas del lenguaje que constituyen técnicas de un protagonista masculino, Gabriel, para exponerse a sí mismo en un espacio público. Este artículo explora estas prácticas en el contexto de la novela como totalidad y en dos escenas en donde se representa a Gabriel en situaciones de confrontación, primero con la autoridad paternalista encarnada por su padre, Don Vasco, y luego con la sexualidad femenina encarnada por su colega de la escuela, Elena Viales. El artículo identifica dos figuras del lenguaje que están implicadas en estas escenas: la subvocalización, definida en los estudios del alfabetismo, y el choteo, definido previamente en la obra de Oreamuno. Estas figuras contribuyen al fracaso del uso del lenguaje público del joven sujeto masculino. El artículo también describe el escenario político-lingüístico costarricense en el que se escribe la novela. Para ello, recurre a descripciones que Oreamuno aporta en su escritura crítica, publicadas en la revista Repertorio Americano entre los años 1936 y 1948, y a las repuestas de sus contemporáneos. Estas delimitan y evidencian un escenario represivo en el que la censura directa es sustituida por una tolerancia verbal esterilizadora.

The novel by Costa Rican author Yolanda Oreamuno, La ruta de su evasión (1948), tells the story of a respectable bourgeois family living in San José and its members' attempts to escape their patriarch's subtle but brutal regime of emotional terror. Within this milieu, the character with which the novel is overwhelmingly concerned is the family's youngest son, Gabriel. Intercalated chapters represent scenes in which Gabriel struggles to develop his capacity for speech. In one of two scenes that I discuss in detail in this article, Gabriel attempts to develop a critical discourse about his father. In the other, he attempts to hold a dialogue with a sexual partner. These scenes are truly representations of failure. Gabriel never realizes his discursive goals and ultimately self destructs as a speaking subject. At the end of the novel, he is reduced to repeating a single word, which has no referent in the narration: tzintzuntzan. At the same time, Gabriel's failure as a potential speaking subject is reinforced by the emergence of other empowered speaking subjects. Into the space left by 
his silence or unintelligible utterances these figures introduce their own exploitive or abusive discourses. It is a trajectory that suggests that the central conflict of the novel may be the threat of imposed linguistic isolation. The silence maintained by the female members of Gabriel's household that has already been well explored as constituting a space of dissent is not, however, solely linguistic. ${ }^{1}$ Gabriel wants to speak out in a public situation with and to other inhabitants of the capital who are not members of his family. He is preempted from doing so by actors whose public speech is already formed and continues to formulate itself at his expense.

This central conflict in Oreamuno's novel is foreshadowed in her earlier critical essays, which she published in Repertorio Americano between 1937 and 1948. Here, the author announced her intention to disengage from an autochthonous Latin American literary mode that, for many, was a form of praxis: folklore. At the same time, she also critiqued choteo, a form of Central American wit, as a form of linguistic violence, being language that causes its target material harm. Scholars heretofore have first compared the content of Oreamuno's novel with that of her essays, emphasizing the ways in which personal narrative modes and the characters' separate discourses contrast with the modes and discourses that she herself has criticized. For example, both Oreamuno's apologists and detractors alike concentrate on her use of interior monologue and the way that this shifts the focus of the narrative away from a folkloric Costa Rican landscape towards a psychological landscape, thus allowing her to condemn the repressive practices of the bourgeoisie. This process is somewhat uneven given the vertiginous path that Oreamuno's disengagement from folklore and her confrontation with verbal violence actually take. For instance, she does not completely excise folkloric elements from her fiction. At key moments she represents her characters as being in contact with powerful incarnations of folkloric elements, which threaten them with annihilation. Moreover, whereas in her essays Oreamuno adopts a comic tone to critique the Tican instinct to cajole, in her fiction she portrays this activity as having deadly consequences for her characters.

\section{FORMS OF LINGUISTIC (IN) HOSPITALITY}

When La ruta de su evasión was published in 1948, Oreamuno was best known as a contributor to Repertorio Americano. Between 1936 and 1948 she published a total of twenty-three pieces in what was for almost forty years one of Latin America's most important forums for cultural criticism and literary expression. Oreamuno's earliest pieces in Repertorio 
Americano include flattering reviews of male authors' work, short stories for children, and above all, reflections on the Latin American landscape as something approximating what Lezama Lima called gnostic space, which does not "passively await insemination by a world-historical Idea or Spirit without collaboration" but "contributes to the intrusion of the Spirit" (Morse 88). This space has the power to conceive discourse. Or so Oreamuno wrote in her very early essay, "40o sobre cero" (1937). Here "el deseo de escribir" is posed as "una situación impuesta por el paisaje" and "un proceso del ambiente" and not simply the manifestation of a "necesidad de exteriorizarse" (137). She also uses language for a synesthetic effect, creating surrealistic portraits of Latin American landscape using a verbal palette made up of light and dark, warm and cold, loud and quiet.

However, in her essay published two years later, "El ambiente tico y los mitos tropicales" (1939), the writer parodies her own prose from " $40^{\circ}$ sobre cero" and introduces a negative concept of Costa Rican exceptionalism with ramifications for her view of Costa Rican discourse. She characterizes Latin American landscape proper - that is something like Lezama Lima's masterfully monstrous landscape - not being part of the creation of Costa Rican culture, but instead as having bracketed that process. First, she describes the greater landscape as marginalizing Costa Rica: "Se acabaron al norte los grandes acantilados en donde el agua puja mugiente todos los días, los inmensos desiertos arenosos y hostiles, los pavorosos fríos ... Sólo más al Sur ... comienza nuevamente la sensación de aridez, de impotencia ante la naturaleza, de lucha recia y viril con lo imprevisto" (18). She then turns a jaundiced eye upon Costa Rican landscape in its particular dimension: it is "un cromo delicadamente lindo" (18). This tableau, in contrast with Lezama Lima's imago, penetrates but does not impregnate. Thus, the Costa Rican psyche remains intellectually, as well as discursively, sterile.

According to the novelist Fabián Dobles, some readers felt that Oreamuno indulged in environmental determinism in these essays (Dobles 321). However, "El ambiente tico y los mitos tropicales" presents too sardonic a tone to be taken seriously as a work of environmental determinism. To begin with, it takes a mocking view of those "grandes naciones" (10) whose intellectual accomplishments proceed from an epic struggle with their own wilderness. In her essay, Oreamuno renames these accomplishments "grandes pecados" (10); Costa Rican culture, on the other hand, languishes "virginal," (9) sinning "infinitesimally" when it does sin: "Cometamos todos los días infinitesimales pecados" (9). In fact, Oreamuno's paisajismo is actually a pretext to model a new aesthetic of 
monotony that is not simply realistic but darkly surrealistic. Here she does away with the palette of light and dark, warm and cold, loud and quiet that she employed in " $40^{\circ}$ obre cero". Instead, Costa Rica is monochromatic: the color of the environment is "negro" (6). It is monoclimatic: neither the country of "cero lluvia" (14) or "lluvia bajo cero" (14), it is the country "(donde) llueve nueve meses al año de la manera más desesperante del mundo" (15). Finally, Costa Rica is monolingual: "Indios, hay unos tres mil que viven en el interior de la República ... $\mathrm{y}$, aunque algunos hablan dialecto, todos hablan español" (15).

For Oreamuno, Costa Rica's monolingualism cannot be reduced to the nation's ethnic homogeneity. She is interested in a form of discursive monolingualism that is the gift of bourgeois enterprise. It is the work of maintaining, first, an optimal environment for commerce, and second, an optimal environment for the exercise of what she calls "demoperfectocracia" (21), a cosmetic form of democracy that disguises the chatter and gossip that constitute the real prerogative of Costa Rica's bourgeoisie. ${ }^{2}$ This labour consists partially in the neutralization of presumptive excellence. In Costa Rica, "Esta no necesidad de lucha trae como consecuencia un deseo de no provocarla ... Al que pretende levantar demasiado la cabeza sobre el nivel general, no se la corta ... Le bajan suavemente el suelo que pisa, y despacio, sin violencia, se la coloca a la altura conveniente" (19). Today, this quote has taken on almost lapidary quality, ${ }^{3}$ but it originally referred to something very specific: on the one hand the efforts of the press who bury good ideas in bad writing, and on the other, the tendency of the average Costa Rican to entertain himself by devising unanswerable criticism that would be unintelligible to those targeted and prevent them from ever trying to rebuff the critique. This activity employs a device that Yolanda Oreamuno identifies as choteo:

Además de la ignorancia deliberada y entrenada (diría yo), conocemos las sutiles vertebraciones del choteo. El choteo es una arma blanca, ¡blanca como una camelia!, que se puede portar sin licencia y se puede esgrimir sin responsabilidad. Tiene finísimos ribetes líricos de agudo ingenio; sirve para demostrar habilidad, para aparecer perito, para ser oportuno, filosófico y erudito. Afecta características distintas: el empirismo sociológico, y empirismo freudiano. Además, contra tan fina y elegante arma no hay defensa. Usted la encuentra esperándole en la boca de su mejor amigo, en la mano de su colaborador, en el periódico matutino y en el vespertino; en todas partes. Y lo que más: usted es corajudo, sutil y llama "al pan, pan y al vino, vino" si la sabe usar con acierto. Tiene la ventaja indudable de que usted no necesita respetar a nada ni a nadie, y que no se requiere mayor profundidad para su ejercicio. Creo que es el único tecnicismo verdadero de que 
podemos alardear, y sus "profesionales", los sólos expertos en que abundamos. (Ambiente 2I)

Choteo is a device explored exhaustively by the Cuban cultural critic Jorge Mañach. In his essay "Indagación del Choteo" (1928), Mañach describes it as "un hábito de irrespetuosidad" (I4), that is, a practice, standing in opposition to action, and disrespect in opposition to respect, literally, "respicere: volver a mirar" (15). Choteo therefore has the potential to be "un vicio de óptica mental o de sensibilidad moral" ( 15 ) that manifests itself in a failure to act. In this case, the choteador does not recognize the myriad authorities that make themselves apparent to the virtuous man and call him to action. These are not just institutional authorities, such as the church or government, nor are they the obvious domestic authorities, such as the household patriarch. The marginal and the meek, children for example, have authority as they call upon men to provide care. Likewise, great scholars have authority as they call upon men to study. Insofar as this is the role usually played by choteo, Mañach believes that it is primarily a toxic phenomenon. Choteo will be redeemed, Mañach asserts, only when it represents a selective disrespect for illegitimate authority. For this to occur, for choteo to become a kind of verbal praxis and not just a form of cruelty, the choteador will have to become far-sighted and sensible. His optical disorientation must be corrected.

There is potentially a difference in the way that Mañach, as opposed to Oreamuno, defines choteo in a national context. While the choteador of Costa Rica employs medical, literary, sociological and Freudian empiricism and is published in the papers, the choteador of Cuba is heard on the streets and tends to employ crass, even obscene language. For this reason we might imagine that in the first part of the twentieth century choteo in Costa Rica and choteo in Cuba were merely homonyms, Costa Rican choteo being analogous to English wit or Brazilian esperteza while Cuban choteo would be something else altogether. However, Oreamuno's description, which emphasizes the deadly potential of the device, signals the originally negative judgment that exists in Mañach's work. Granted, this is a negative judgment that contemporary scholars have largely overturned: Roberto González Echevarría and Román de la Campa deconstruct this judgment in a way that allows for the redemption of choteo as a constituent of Caribbean festivity and polyphony. ${ }^{4}$ However, Mañach's original investigation insisted that the victory of choteo in Cuba attested to the spiritual solipsism, egotism or autism of the Cuban subject which did not bode well for the development of an objective, altruistic or truly hospitable sensibility. This is a judgment that remains clear in Oreamuno's work: "El 
choteador) sería inofensivo, si no le faltase, como antes anotara, el simplista sentido de projimidad" (17). For Oreamuno, as for Mañach, the fault in the choteador is one of senseless self-involvement. The fact that Oreamuno identifies instances of choteo in the press, which supposedly performs a documentary function, only underlines her belief that written and oral culture in Costa Rica were in fatal collusion. The verbal sins that the everyday Costa Rican committed on the street were patterned on, reproduced, supplemented, or provided an alibi for those that appeared in print.

Yolanda Oreamuno's conception of Tican monolingualism constitutes part of her vision of a hospitable Costa Rica. Here, Oreamuno employs the word hospitable (acogedora) sardonically. Costa Rica is hospitable in the sense that it physically receives people from all over the world: political refugees and exiles included. However, this capacity to receive physically, that is, the physically inviting, seductive, aspect of Costa Rica, is predicated upon its spiritual infertility:

Costa Rica acogedora recibe con los brazos abiertos a los emigrados políticos de toda América, a los víctimas de 'X' y 'Z' tiranía. Los periodistas le hacen una visita, le toman el pulso, y si ven que el señor insiste en su innata rebeldía, se le ignora suavemente, y suavemente pasa también al anonimato definitivo. Grandes figuras políticas, literarias, revolucionarias y demagógicas han pasado tiempos de destierro en Costa Rica, y de su estado no existe más ... que el nombre en las listas de inmigración. (Oreamuno, Ambiente 20)

Consequently, to speak of a language of hospitality in Oreamuno's work is really to speak of a brand of "contraceptive" language.

Oreamuno believed that the persistence of costumbrismo as a literary mode in Costa Rica in the 1930 was a sign of the sterility of the cultural landscape. This is the central idea expressed in "Protesta contra el folklore" (1944), Oreamuno's most (in)famous article. Here, she expresses her exhaustion - "literariamente, confieso por mi parte, que estoy harta, con mayúsculas" (96) - with what she calls alternately folklore or costumbrismo. In its ideological dimension, this is literature that corresponds to "el imperativo histórico (de cada nacionalidad) de lanzar la verdad dolorosa que penan, respectivamente, el indio, el cholo, el campesino, el mestizo y el criollo" (Oreamuno, "Protesta" 94). In its aesthetic dimension, this is literature that accomplishes verbally, via transcription, what the casta paintings of old accomplished visually, voicing the races of Latin America: "el léxico se hincha con palabras de atl, istl and chua..." (Oreamuno, "Protesta" 94). Oreamuno is explicit about the 
source of her exhaustion. It stems from her feeling that she has read the absolute best that the genre has to offer and that she is ready now to read a new kind of fiction that treats explicitly the psychological realities of urban life in Latin America, including bourgeois life, as it has been inspired by Yankee economic imperialism.

In truth, "Protesta contra el folklore" is a short, straightforward piece of writing, yet the chastising responses that it provoked provide an object lesson in the kind of discursive (in)hospitality that preoccupied Oreamuno. Shortly after its publication an erroneous rumour spread that it contained a protest against folklore based on the idea that Costa Rica itself did not have either enough folk or folk practice to write about. Costa Rican writer Fabián Dobles attests to the existence of this rumour and calls it fallacious. In reference to a critique that appeared in El Tiempo "(Oreamuno) rehúye (el folklore) por estimar que ... en Costa Rica no hay material suficiente" (Dobles 32I) - Dobles says, "Nos negamos a creer que ... haya sido otra cosa que una desviada interpretación del periodista al expresarle la escritora su posición subjetiva enfrente del movimiento novelístico costarricense" (32I). However, in a moment that now appears key and hints at the importance that such a rumour might have had for a young writer's reputation, Dobles did not defend Oreamuno in any straightforward way. Rather, Dobles, a close contemporary of Oreamuno who participated in the same literary competitions asserted that even though this was not her meaning, for Oreamuno to have written an article that had even the potential to be misinterpreted in this way was "peligroso" (Dobles 322). ${ }^{6}$ This condemnation precedes a passive aggressive dismissal of what he understands Oreamuno to have wanted to do in her own writing: "Hemos de advertir que respetamos que una escritora, cualquiera que ella sea, juzgue que debe hacer 'novela psicoanalista y socialista'. He aquí un problema individual que solo el propio interesado debe resolver" (Dobles 322). ${ }^{6}$

Beyond asserting that her psychological approach to literature was unpatriotic, Oreamuno's critics maintained that it was derivative and underwhelming. Critics like Seymour Menton and Abelardo Bonilla both claimed that La ruta de su evasión, as well as Tierra firme, manifested the influence of James Joyce. According to Menton: "Sus dos novelas, Tierra firme (inédita) y La ruta de su evasión (1949) ... reflejan la influencia de Joyce en la penetración del subconsciente" (qtd. in Urbano 178). For Bonilla, "Sus primeros ensayos revelan la influencia de Mann en el tema del tiempo y la del Proust en el tratamiento de los temas del recuerdo. Más tarde fue Albert Doblin el autor que la impresionó y finalmente prevaleció Joyce, cuyas huellas son palpables en 'La ruta de su evasión'” (354). Bonilla 
specified that this was a frustrated manifestation, for Oreamuno was tragically unable to use interior monologue in Joycean fashion:

Se empeñó a retar a la vida y en superar, en el campo de las bellas letras, lo que la vida no quiso darle. Y en esta empresa fue más allá de sus posibilidades. En su primera obra de fuerza, la novela, 'Tierra firme', se revelan sus grandes condiciones y también sus limitaciones. La primera parte - sus recuerdos de infancia, lo vivido y lo cierto - es excelente ... La segunda parte, en la que se aparta de su campo y ensaya la aventura conceptual, es muy inferior, como lo es literariamente su segunda novela, 'La ruta de su evasión'. (354)

These assertions aggravated the Costa Rican playwright Victoria Urbano, one of Oreamuno's greatest devotees, both because Oreamuno routinely asserted that she had never read Joyce and because Urbano did not believe that Menton, at least, had ever read Tierra firme (Urbano 178). The novel had shared a prize for first place in the Hispanic American Writers Contest run by the New York publishing house Farrar \& Rinehart, but Oreamuno had refused to let Farrar \& Rinehart publish it and later denied knowledge of its fate. ${ }^{7}$ Quotations from Menton and Bonilla therefore suggest that some of Oreamuno's harshest critics possessed only second-hand familiarity with her novels. In addition, their assertions constitute a masculine criticism that Oreamuno denounced in the brief but intense correspondence that she exchanged with Victoria Urbano after the publication of La ruta de su evasión. Here, Oreamuno emphasizes the dichotomy of response that her experiment in psychological fiction received from female and male audiences: "Es curioso, pero la respuesta mejor a mi libro la he recibido hasta ahora de mujeres" (qtd. in Urbano I9I). Urbano accounts for this dichotomy in her I968 monograph, Una escritora costarricense: Yolanda Oreamuno. Relying heavily on the work of her colleague, Costa Rican intellectual Lilia Ramos, she anticipates postmodern feminist theorizing and judges that Oreamuno's use of psychological narrative techniques such as stream of consciousness is justified by the inherent value of her project, which is the verbal extraction of a tortured feminine subjectivity that achieves an unassailable opacity. The apologetic writings of both Urbano and Ramos respond to a discourse about La ruta de su evasión that these women perceived as damaging to Oreamuno's career.

The Novel as a Whole: Relaying Discourse

La ruta de su evasión is comprised of twenty three chapters. Some of these resemble examples of short fiction in that they tell self-contained stories 
from the perspective of a single character. Others possess a more truly novelistic quality. They refer to one another and their subdivisions correspond to shifts in perspective among multiple characters. The fragmented composition of the novel produces a phenomenon of "soledad en que (los personajes) están inmersos y ... falta de solidaridad colectiva" (Martínez 66). However, if it is true that the novel's characters live immersed in a "mundo aislado con sus problemas particulares" (66), this does not preclude feeling empathy for one another. Empathy, and ultimately an individualistic embrace of survival, replace "todo ideal que les sirva (a los personajes) de aliciente para superar sus circunstancias particulares" (67), thus marking the narrative as distinctly and selfconsciously bourgeois. While this article focuses on the disintegration of Gabriel as a speaking subject, the novel as a whole may be summarized as a cycle of verbal disintegrations and integrations that propel empathy and engender survival; almost a verbal, emotional, and libidinal relay race.

At the beginning of the novel, Gabriel is living at home with his father, Don Vasco, his ailing mother, Teresa, and his two brothers, Roberto and Álvaro. Both the discourses and sexuality of the brothers are dictated by their father, who prioritizes his sons according to their birth order. He has prepared his eldest, Roberto, to replace him as patriarch and has strategically neglected the other two. Roberto, therefore, speaks with authority and uses ridicule, although his discourse, which is stilted and over-determined by his obsession with healthy eating and physical fitness, is absurd. Roberto is also allowed to marry and bring his wife, Cristina, home with him. Alvaro, on the other hand, as the youngest brother, is laconic and is limited to expressing his sexuality through compulsive masturbation. Gabriel exists somewhere in between, a bookish young man who uses his literacy to spar with Roberto, but who has difficulty speaking to his peers. The only interlocutor he has is his mother's maid, Aurora. However, Gabriel seems to disdain Aurora and resent that she understands him. Teresa herself speaks little but has a rich interior monologue.

Of the three brothers, only Roberto survives his upbringing. After Cristina dies in childbirth, he begins to speak forcefully. He confronts Don Vasco, accuses him of terrorizing the family, then leaves the house forever. Alvaro, however, never acquires either proper discourse or healthy sexuality, and Gabriel eventually unravels, his attempts at self-expression giving way to gibberish and finally muteness. His sexuality, which he attempts to express first to a student colleague, Elena, is frustrated, and he later capitulates to be with Aurora. Meanwhile, Teresa's capacity for outer speech declines until the narration is confined to her interior monologue. Because Teresa has insight into her children's experiences her discourse 
comes to resemble an omniscient narration. Teresa's interior monologue disappears shortly after her death midway through the novel and her point of view is replaced by that of Aurora, who becomes the true protagonist. Aurora retains a clear memory of Teresa's advice for constructing a happier life beyond the walls of the Vasco household. The novel ends after she witnesses Gabriel's suicide, at which point she feels that she is able to apply these lessons.

The novel largely neglects the perspective of Don Vasco. Consequently, he does not appear as a protagonist of the cycle described above but is completely identified with the environment, or house, where it takes place. Vasco is power demoperfecto. Although he possesses some stereotypical and even folklorical machista vices - he gets drunk and is also a philanderer - his most important characteristic is his empiricism. He is self-consciously and intelligently cruel and his cruelty always supports the project of maintaining bourgeois and patriotic respectability. It fortifies the household as a sovereign space, it procures the labour of the households' female members and it assures its own uneven reproduction in his sons. Additionally, Don Vasco's cruelty is an outlet for his own considerable creativity. On a day to day basis, he enjoys the creature comforts of bourgeois life, yet he also creatively contrives to turn those comforts into terrifying symbols for his family. For instance, he provides better care for his dogs than for his children, a gesture that terrifies Teresa, who interprets it as a sign of the children's disposability. Don Vasco's representation of repressive, sterilizing power is further suggested by the fact that he engineers the exile of his friend Esteban, who is his wife's only full conversational partner.

I shall now present two scenes of linguistic violence from La ruta de su evasion. Both depict the linguistic sterilization of the character Gabriel. The order in which I present these scenes reflects the order in which they are sequenced in the novel. The first is about a metaphorical readership. Gabriel attempts to read his father in order to locate him in one of San Jose's brothels. However, his reading proves to be a futile activity. In order to explicate this scene I shall introduce a new figure of language: subvocalization. The second scene is, in contrast, about the end of readership. Gabriel will be forced to put down a book and talk to a sexual partner. In this scene we will return to the figure of choteo. I shall argue that Gabriel is subjected to a radicalized, perfected form of choteo identified with the automation of middle class, educated women. I shall end this discussion by specifying the consequences of this sterilization. 
SCENE 1: NO, NO QUIERO IR ALLÍ

In this scene, Gabriel practices a type of language that I understand, metaphorically, as a form of subvocalization. The term subvocalization has been appropriated from literacy studies. It is, in fact, a figure cut from that field. ${ }^{8}$ In literacy studies, subvocalization is the technical term that refers to what we commonly call "reading under one's breath," which is different from "reading out loud." While reading under one's breath means to speak, it does not involve speaking to someone. A literal example would be a reader moving their lips, their mouth or even their throat muscles as they read, while not producing any audible sound. Furthermore, literacy studies have traditionally posited subvocalization as a rudimentary type of reading. On the one hand, pedagogues have encouraged subvocalization assuming that it belongs to an interstitial stage in the development of true literacy. On the other, pedagogues have discouraged and even punished subvocalization in order to ensure that this stage gives way to the next. According to this model, true literacy emerges as the subvocalizations of the pupils are transformed into an interior monologue and is only fully accomplished as this interior monologue - occasionally considered an advanced form of subvocalization in its own right - becomes subjectively indistinguishable to the pupil from his/her own thoughts. The fluent reader, the critical reader, is able to direct itself towards the meaning of the text $\mathrm{s} / \mathrm{he}$ reads as a pure object. This philosophy has caused certain harm. It has inspired some truly brutal pedagogical techniques, including techniques such as gagging the reader to prevent subvocalization. ${ }^{9}$

The scene begins with an interpellation. Gabriel's older brother, Roberto, calls to him, "Gabriel, ve a buscar a papá" (9), and Gabriel responds, not verbally, but physically by starting to walk. This physical response is only a physical response. A narrator states that Gabriel walks without thinking, "Camina mucho rato. Vacío de pensamientos" (10). At the same time, the narration explicates the phenomenology of the totally physical response. ${ }^{10}$ First, between its utterance and Gabriel's corresponding movement, the phrase "ve a buscar a papá" seems to reverberate. This happens through the repetition of the line within Gabriel's inner monologue. Gabriel thinks, "Gabriel, ve a buscar a papa, eso fue todo. ¿Por qué yo y no él?” (9). Most importantly, this interpolating phrase is suggested as having special content. Although Roberto does not tell Gabriel which way to go to look for their father, Gabriel thinks that Roberto's voice seems to signal without mentioning this content: "Tiene su voz una nota y su gesto una intención que parecen señalar crudamente el camino sin mencionarlo. ¿Por qué pienso esto? ¿Por qué pienso que es eso?" (9). For Gabriel, the way to go will mean speaking realistically about 
the power structures that exist in his home. Specifically, Gabriel will have to describe his father.

This is determined when, after walking for some time, Gabriel gets into a taxi. At this time, Gabriel is silent. It is the driver who must speak first and ask him where he wants to go: "Toma un coche, y cuando el chofer pregunta la dirección, su turbada cara es para el experto la mejor respuesta. Lo mira. Repite la pregunta" (12). Gabriel responds, "No, no quiero ir alli" (12).This response interrupts what would have been a natural discourse between Gabriel and the cabbie. Effectively, the cabbie has asked Where do you want to go? and Gabriel has replied, No I don't want to go there. There is a critical non-correspondence between the interrogative where and the referential pronoun there.

Only the effect if not the sense of Gabriel's response may be appreciated upon comparing the original phrase "no quiero ir alli" with the subsequent clarifying statement that Gabriel proffers, "Dije mal. Sí quiero ir ahí, pero no soy yo él que quiere" (12). Gabriel does not want to go "alli" but does want to go "ahí." He wants to go, but it is not he who wants. The negation and the affirmation cancel one another out and we are left only with the deictic and subjective twinnings: allí/ahí and yo/él. These twinnings stand in for an implicit desire which is also a destination: the father's desire and the brothel where he fulfills it. This is not yet an integrated discourse that anticipates Gabriel's subvocalization.

The cabbie offers to take Gabriel to a brothel, but Gabriel has not the slightest clue as to which of San Josés brothels his father might have chosen. The cabbie therefore elicits a description of Don Vasco from Gabriel for the purpose of determining which brothel they should try first. The nature of this exchange belies Victoria Urbano's claim that Oreamuno's "literatura urbana" (56) does not configure human misery within economic relationships, for there is a strong economic dimension to this exchange. First, both Gabriel and the taxista are strongly concerned with the idea that speech can be quantified as insufficient, sufficient or excessive within an economic schema. Gabriel, for instance, is worried that he will say too much: "Otra vez estoy diciendo más de lo necesario ... Mis palabras salen por si solas. Esto es lo que menos quería decir, y lo he dicho" (13). Meanwhile, the cabbie needs Gabriel to describe his father in enough detail so that he can be sure to avoid the right brothels long enough to take all of Gabriel's money: "Después de todo es un buen negocio; toda la noche rodar ... Lo llevaré primero allí en donde seguramente no está. Si lo conociera ... Si me lo pudiera pintar" (13). In this way, storytelling is configured as an economic loss for the storyteller and as an economic gain for his listener. 
Additionally, Gabriel worries about the impropriety of his speech. That is both the possibility that in describing his father he will say something unsuitable and that he will express a thought that is not proper to him, Gabriel: " $\mathrm{i} M a l d i t a$ sea! Ya me pierdo, estoy diciendo cosas que no entiende nadie. Y siento que diré cosas peores" (12). This worry intensifies as Gabriel senses that he is being provoked by the enquiries of the cabbie. When the taxi driver asks Gabriel, “¿Cómo es su padre?” (13), Gabriel's inner voice responds, "¿Qué cómo es él? ¿Qué tendrá que ver esto con que lo encontremos? Nunca había pensado antes cómo es él. Lo he sentido. Algo así como un peso encima. Pero no lo recuerdo. Veo la casa ... Pero no él. Sé cómo es. Veo las palabras con letras que corresponden a su fisonomía. Pero no puedo ver su cara" (14). Here is the crux of the problem: the words with the letters that correspond to the father's physiognomy. Gabriel's inner voice reflects upon these: "Palabras, palabras de consonantes y vocales, sonidos, oídas dentro, formuladas afuera" (14).

Two things are happening to Gabriel at this moment. Both involve a struggle of perception that is, basically, a struggle to bring into focus a figure against its background. This is taking place both on the level of Gabriel's imagination of his house and on the level of his discourse about his father. Gabriel must constitute the figure of his father by recognizing in him the qualities that he is as yet only able to recognize in the house. Though he knows, preternaturally, that these qualities are already those of his father. For Gabriel, this is a literary experience. These qualities are subdivided into words and letters. Bringing them from the house and into the father will be like hearing the words on the page, a subvocalization. This is the fullest, most complete reading of Don Vasco that Gabriel comes to express:

Es arrogante, violento, le gusta que le obedezcan. Se hace obedecer. Es ... ¿Cómo le dijera...? Es vanidoso. Se preocupa mucho de su propia persona. No se preocupa nada de los demás. Nunca ha dicho a qué sitios va ni nadie se atrevería en la casa a preguntárselo. Ni cuando regresa. Creo que le preocupa mucho, muchísimo, lo que los demás, que no son de la familia, piensan de él. Me parece que siempre está tratando de aparentar lo que no tiene, lo que no es. Con los extraños es muy generoso, muy cortés; con nosotros es duro, implacable. No tiene compasión de nosotros. Nunca demuestra nada. ¡Es cruel! ¡Oh! ¡Es muy cruel! (14)

The question is whether Gabriel is able to interiorize this reading and become an accomplished reader after this subvocalization.

Gabriel is able to internalize the content of this reading with mixed success. On the one hand, he feels alienated by his own words: "Nunca me 
las hubiera dicho ni a mí mismo" (15). On the other, he now judges that the words are sufficient: "Nada sobra. Es así" (15). The sufficiency of Gabriel's speech is proven by his acquisition of a distasteful but realistic idea of his father. "¿Pero es que para hacer una pintura realista de él debo recurrir a ideas tan desagradables?" (15). In this way Gabriel comes to repair albeit partially his subvocalization, transforming it into a genuine reading. However, the majority of the chapter that opens with this scene actually takes place after these linguistic accomplishments. What concerns us, then, are their consequences, which include an apparent and paradoxical selfbetrayal on the part of the now speaking subject, Gabriel.

As the night wears on, Gabriel begins to express what originally he could not stand to read in his father: a sadistic misogyny. This expression is at first practiced. The first time that Gabriel visits a cantina during his search, he thinks to himself about the women there: "Yo no vengo a golpear, vengo a buscar a mi padre, debieran saberlo, no quiero que estas mujeres piensen que vengo a golpearlas; no le pegaría a alguien atado ... ellas están atadas" (19). However, later in the evening, Gabriel does sleep with and beat a prostitute: “¿Era eso tocar? ¿Era eso golpear?" (24). Afterwards, this expression is articulated. In the last cantina he visits, Gabriel issues a discourse that is properly his father's: “¿Para qué sirve el cariño? Que se me ... odie ... y respete ... así es mejor ... Siempre se lo digo ... Como a ti ... Es ... una idea ... mía" (25). Confirming that Gabriel is now a quoting, rather than a speaking subject, at the end of this vignette there is a shift in subjectivity. In a nearly singular instance, Don Vasco appears as a protagonist and it is through his ears that we hear Gabriel. Don Vasco recognizes the appropriation of his own discourse and becomes enraged. However, his rage does not stem from a feeling that he is being mimicked. Rather, Don Vasco feels that, along with words that might have been his, his philosophy has been appropriated: " $\mathrm{i} Y$ ese imbécil se permite exponer como suya la idea del respeto!" (26). His subsequent punishment of Gabriel, whom he drags out of the cantina and back home, may be taken as a sort of anti-pedagogy. Don Vasco has preempted Gabriel from interiorizing a philosophy from which he, Don Vasco, derives power.

SCENE 2: TE VOY A CONTESTAR TODAS LAS PREGUNTAS QUE PROBABLEMENTE INTENTAS HACERME

This second scene portrays the development of a sexual relationship between Gabriel and his schoolmate, Elena Viales. Educated, outwardly articulate and sexually assertive, Elena is a foil for all of the female characters that belong to the Vasco household. More importantly, Elena has been suggested by critics as an avatar for Yolanda Oreamuno herself. 
Victoria Urbano, alluding to Yolanda's practice of signing her work simply "YO," wrote: "Con el personaje de Elena tenemos ya una visión completa de ese YO interior de la autora que actúa en el mundo de sus ficciones" (145). Urbano also believed that Elena was an aspirational figure in a general sense: "La única que parece luchar por su libertad es Elena" (145). More recently, Herbert E. Craig, writing on the history of the psychological novel in Latin America after Proust, has posited that if Elena was supposed to be an aspirational figure, she still invokes Oreamuno's internalized chauvinism towards Latin American women: “(Elena's father) ... was of French origin and very wealthy. Dissatisfied with the submissiveness of Hispanic women in general and of his criolla wife in particular, he raised Elena as a free spirit and he encouraged her whims. Here we can see one aspect of Oreamuno's critique of timid women, but also a facet of her own personality, which struggled to be free" (103).

A close reading of Elena's discursive practice, however, supports a very different understanding of the character. Elena is the novel's most accomplished practitioner of choteo. She calls a spade a spade, encountering the discourse of others with radical objectivity and yet with zero respect. As a choteadora, Elena stands as an unparalleled destructive force in the novel and chief agent of the linguistic sterilization of Gabriel.

We first meet Elena when she interrupts Gabriel as he is reading: "¿Qué lees?" (110). Gabriel then reflects on the harm these words have caused: "Como ya nadie aquí le habla, por estar habituados a su silencio, Gabriel la mira con la sorpresa de quien ha sido despertado en la profundidad de un sueño. La sorpresa tiene grados ... como en las quemaduras, quemadura de tercer grado. La de tercero, es porque ella no lo conoce" (111). Gabriel does not respond to Elena's question aloud. Instead, his inner voice responds by formulating its own questions, "Debe de ser de segundo curso, porque las mujeres nunca pasan del segundo curso, a menos que sean muy feas ... aunque sean inteligentes no pasan de ahí, les da miedo. En medicina, porque el profesor de anatomía hace preguntas ofensivas" (113). At the same time that Gabriel's inner voice formulates these questions, Elena states that repeating oneself is a liability of women. She tells Gabriel that she will not repeat herself. Instead, she repeats Gabriel's thoughts for him: "te voy a contestar todas las preguntas que probablemente intentas hacerme: estudio medicina, estoy en el cuarto curso; no me dieron miedo en el primero las preguntas de los profesores ... les di yo miedo a ellos" (114).

In this way, Gabriel's inner voice pairs with Elena's outer voice in a curious fashion. Whatever Gabriel thinks to himself, Elena later articulates. The result is a redundancy on the level of discourse similar to quotation. 
Gabriel's interior monologue reappears inside of Elena's direct discourse, but Elena's monologued dialogue (to invert a phrase used by Urbano, monólogo dialogado ${ }^{\mathrm{II}}$ ) also mirrors subvocalization. Subvocalization, as we have seen in the case of Gabriel, is a discourse that represents a jump: the elimination of a moment of necessary encounter between the subject and the content of his discourse. Elena's monologued dialogue also represents a jump. Yet this is not a jump necessary to the production of an ontological subject predicated upon the content of his discourse. Rather, this is a jump necessary to the production of a social subject. By cold reading Gabriel, Elena takes the upper hand and deprives Gabriel of the chance to emerge as a conversational subject.

At this point, Elena invites Gabriel to conduct an autopsy with her. Gabriel silently consents and the two move to a private autopsy bay that Elena's father has had built for her in their home. Here, Gabriel and Elena find a body already laid out for them but covered by a sheet. As Elena invites Gabriel to see the body and folds backs the sheet Gabriel thinks about peeling a fruit. The body is revealed to be that of an Indian woman. The autopsy itself is narrated entirely by Gabriel's inner voice, which uses the future tense: "En ese vientre entrarán su bisturí y el mío, y se encontrarán sobre la misma herida que ya no va a sangrar ... En esta inútil violación, el olor corrompido de la india muerta llegará directamente a su nariz que no ha de notarlo, y a la mía que insistirá por encontrar, no el olor del cadáver, sino el olor de ella" (119). Here, the future tense represents the dispersal of Gabriel's desire for Elena. With the body present, this is a triangulated desire: "(Elena) estará a un lado y yo al otro, y entre los dos, quedará el vientre de la muerta, su vientre de seguro fértil" (120).

During the autopsy, Gabriel chooses to dissect the woman's skin. His interior monologue explicates this choice:

Yo prefiero mirar de cerca esta piel melosa ... quiero mirar en la célula la reacción del sol y adivinar en cada poro el pueblo de su nacimiento; si la quemó el sol de altura o la doró bochorno de costa, quiero ver si es india de casta noble, porque entonces tendrá el poro fino, y no faltará ni sobrará una sola capa en su piel perfecta, y la grasa debajo será blanca ... y suave. (120)

Inscribing inherently insignificant sub-phenotypical traits in a mythic historical narrative, this explication parodies a folkloric discourse. Elena will in short order extract this discourse from Gabriel.

After the autopsy, Elena takes Gabriel into her salon, where she offers him what she preternaturally knows to be his first glass of whiskey. She asks him not to dissimulate about this. Then she tells him something 
unprecedented: As a scientist, she is not able to think or speak the way that she knows that he is able to think and speak. That is, she is not able to think or speak abstractly: "Puedo entender (el pensamiento abstracto) pero no puedo llegar a él por mi misma" (126). Elena uses this confession as a pretext to exhort Gabriel to model abstract thought for her. What was he thinking, for instance, as they were performing the autopsy? It is under these conditions that Gabriel repeats himself, or his own interior monologue. At the same time, he tries to challenge Elena's preternatural knowledge of him:

¿Recuerdas que te dije yo escojo la piel? Habrás que saber que lo hice porque esperaba encontrar allí el síntoma de alguna curiosa enfermedad. Estabas equivocada ... Pensé que la piel tenía un color prieto, y que bajo ella, la grasa sería más blanca ... yo escogí la piel; no para encontrar allí la rara enfermedad ... sino para mirar en el grano de esa piel la casta, y en el color de esa piel el pueblo de su nacimiento. (128)

Here Gabriel probably comes closest to assuming the role of a proper speaking subject who is able to exteriorize his thoughts. This is true even if the tiresome way in which his interior monologue now reappears inside his direct discourse hints at some persistent organic pathos. And Gabriel will try to obtain leverage during this exposition finally to overwhelm Elena. The chapter ends as Gabriel, having adopted some of Elena's candor, her "descaro" (127), threatens his colleague with a passionate kiss: "Voy a besarte" (135).

Elena, however, deflects and deflates this threat. Before he can make such declarations, she tells him, "Tienes que saber cuál es tu deseo. Y yo te lo voy a decir para que te familiarices con él" (134). His project, she affirms, is not to kiss but to humiliate her ("Tu deseo no era besarme, o si lo era, por encima de este estaba el de humillarme" [134]). Furthermore, Elena clarifies that Gabriel has sabotaged his project by speaking before kissing: "(Humillarme) lo conseguías con la palabra más que con el gesto. Por eso hablaste. Oye esto, Gabriel, y no lo olvides nunca: casi todo lo que es verdad es silencio. Casi todo" (136). In this way, Elena not only affirms that she remains closer to the source of Gabriel's discourse than does Gabriel himself, but also asserts her own non-proficiency in abstract thought as the source of her superiority and greater power.

Elena, far from representing a complete vision of Yolanda Oreamuno's $Y O$ interior, has no interiority. She is supplied by the narration only with a direct discourse patterned off of the interior monologue of Gabriel. However, this is not the imitation by one who is less powerful of someone 
more powerful. Nor is it the imitation of one who mimics or cajoles as an act of resistance or dissension. Nor is it even the verbally violent act of one who seeks to humiliate another through mockery. Rather, Elena, as mimic, is the blunt tool of a larger, sterilizing verbal violence.

In fact, Elena Viales appears as a sort of Frankenstein's monster, pieced together and animated by a single, masculine, human creator: her father. Fernando Viales, is a perfect representation of the "emigrado politico" that Oreamuno wrote about in "El ambiente Tico," who is neutralized by means of indiscriminate toleration. He is a French expatriate whose radical positivism has flourished, unchecked, in the Costa Rica acogedora. Viales claims that Elena is his sole and intentional creation. She has no mother, he claims. She is a "criatura transitoria," (218) or intermediate species, that he alone has created as part of a process of preparation for the emergence of a final creation which will be "un tipo nuevo de mujer consciente" (218). She possesses in part the capacity to be useful and happy that the late species of woman will possess in full.

Adolfo Castañón has described succinctly, but accurately, the wholly inappropriate relationship that Fernando Viales has with his daughter. Castañón suggests that Mr. Viales' dedication to Elena's formation as a scientist constitutes a form of intellectual grooming that parallels sexual grooming: "Elena Viales, la joven rica, estudiante de medicina, ha sido educada, modelada por su padre, don Fernando, como una obra de arte de la mentalidad emancipada; es una hija dizque superior a cualquier hombre y prometida implícitamente al incesto" (220). Castañón's invocation of incest is supported by the way that Elena and Gabriel's relationship ends. In a key moment coming late in the novel, Elena's father approaches Gabriel and invites him, explicitly, to have sex with his daughter. He requests, however, that Gabriel refrain from asking Elena for her hand in marriage. He tells Gabriel that the capacity for even partial happiness, for even rudimentary usefulness, that he has instilled in Elena is not yet so ingrained in her that it could not be sabotaged by the sensibilities that marriage and the reproductive duties entailed by the institution imply.

This scene hints at the fetish of cuckoldry, which is treated throughout La ruta de su evasión as a sadistic rather than a masochistic perversion. For instance, earlier in the novel, Gabriel's own father, realizing that his friend Esteban and wife Teresa are in love, invites Esteban to visit the household on a weekly basis to hold talking dates with Teresa. The dates are proposed as a type of conversation therapy for Teresa. By speaking regularly with Esteban, whom Don Vasco judges to be level-headed, free of any neurosis, the neurotic Teresa should learn confidence and psychic poise. Of course, the subtext of this invitation is that Gabriel's father wishes 
to torture both parties by forcing them into poignant proximity. We should not consider that this act has any masochistic overtones because Don Vasco feels no love for his wife and is not jealous of his friend. Moreover, he can be confident that by lending their conversation his seal of approval, it will be neutralized; and in fact, the neutralization of Esteban's conversation is symbolically echoed in his eventual exile from Costa Rica. Similarly, when Elena's father invites Gabriel to have sex with his daughter, the stipulation that the relationship should have only a recreational aim ironically ensures that it can never become a source of true jouissance. Elena, far from occupying a space of productive struggle, dwells in a netherworld of perfected, penetrating but ultimately sterile and sterilizing physical and conversational intercourse.

\section{CONSEQUENCES OF LANGUAGE VIOLENCE}

In these two scenes of verbal violence we see the following. In the first, the character Gabriel proffers a critical direct discourse about his father without developing a corresponding interior monologue. This results in his self-betrayal and in an anti-pedagogic disciplinary action enacted by the father. In the second, the character Elena Viales draws Gabriel's interior monologue out from him or exposes it before him, with monstrous surgical precision. Both these instances represent dysfunctional forms of discourse on a formal level as they work to de-sequence the temporality, spatiality and subjectivity of discourse that makes it productive. Here thought does not precede discourse, speech can exist outside of the speaker before it has to be found within, and an aggressor can impose herself between another person and his own speech. However, the dysfunctionality of Gabriel's discourse is also proven by his ultimate destiny in the novel. In the end, he sets up house with one of his family's domestic servants, Aurora. Yet this is not a proper elopement. The unmarried, cohabiting couple do not pretend to carry out the typical, productive operations that would sustain a household and that, in the absence of a formal contract of marriage, most fully signify defiance. Only Aurora works. Gabriel, meanwhile, disappears into a reverie in which there resounds a single utterance: the Aztec word Tzintzuntzan. The word is not supplied with any referent inside the diegesis. Extra-diegetically it is the name of a Michoacán town and the name of an Aztec hummingbird deity (Urbano: 202). But these facts are not provided by the text of the novel: "Que quiere decir esta palabra que se me mete ahora en el pensamiento? ... Averiguaré qué quiere decir. Más tarde" (314). ${ }^{12}$ In the text, the phrase is a sort of artifact discourse, part of a verbal landscape rather than a proper discourse. Gabriel repeats this word seventy-four times before Aurora finally agrees to shoot him in the head. 
Gabriel, before dying, becomes a sort of costumbrista, a solipsistic appropriator of local colour. Here, in the end, Oreamuno tips her hat at her folklorist contemporaries, maybe throwing them a bone or maybe making fun.

Cornell University

\section{NOTES}

1 On linguistic isolationism in the work of Oreamuno, see Janet Gold: "These stories show women who survive, who confront loneliness, isolation, fear and death; and from their inner resources they create what they need to sustain themselves" ("Feminine" 195).

2 The connections drawn by Oreamuno between gossip and democracy call to mind the work of her contemporary, the fascist philosopher Carl Schmitt. Furthermore, Oreamuno's criticism of the bourgeoisie echoes Donoso Cortés, as quoted by Schmitt: "According to Donoso Cortés, it was characteristic of bourgeois liberalism not to decide in this battle but instead to begin a discussion. He straightforwardly defined the bourgeoisie as a 'discussing class,' una clase discutidora. It has thus been sentenced. This definition contains the class characteristic of wanting to evade decision. A class that shifts all political activity onto the plan of conversation in the press and in parliament is no match for social conflict" (59).

3 A version of this quotation appears in Ramírez's La fugitiva. However, in Ramírez's novel it is the character Manuela Torres, based on the real life Chavela Vargas, who speaks this quote: "Cada vez que he regresado a Costa Rica ha sido para arrepentirme una y otra vez. Qué país. La ley del serrucho. Si te alzas más alto que los demás pendejos, no te serruchan el piso, te serruchan las piernas para dejarte al mismo nivel" (Ramírez 232). Ramírez also recycles this quote in an interview about his novel: "Yo quería hacer énfasis en la novela en que se trata de una sociedad patriarcal muy conservadora, que pretende reducir a la mujer a un lugar, que cuando intenta sobresalir le serruchan el piso o le cortan las piernas" (Bermúdez).

4 Roberto González Echevarría argues that Mañach fails to include realistic examples of choteo in his study. These would support the claim that choteo is closely related to González Echeverria's concept of fiesta: "The strongest link of the practice of choteo with the festive is through its thrust to freedom and its association of sexuality with death" (140). Román de la Campa contrasts Mañach's choteo, what he calls a "passive mimesis" (112), with another form of 
choteo that is an "interesting and innovative form of mimicry" related to Édouard Glissant's notion of diversion (97).

5 "Given the high esteem accorded costumbrista writing in Costa Rica since the nineteenth century, and the number of writers who practiced it, many Costa Ricans considered ["Protesta"] an affront. Subsequent literary historians, however, have recognized the literary possibilities of urban existence" (Gold, Reading 216).

6 Dobles's tone is echoed in the writing of his and Oreamuno's contemporary, Seymour Menton, who consistently portrays Oreamuno's psychologically focused approach to literature as anti-Tico: "Contraria a la reserva natural de los costarricenses, Yolanda Oreamuno expone los pensamientos y los sentimientos más íntimos de sus personajes" (Menton 29).

7 Lilia Ramos provides a succinct summary of this event (168). Luz Ivette S. Martínez speculates about the current whereabouts of the novel (58).

8 The term subvocalization was originated in this context by Edmund Huey in 1908, although, he originally refers to it as "inner pronunciation" or "inner speech." Also related is what Huey calls "word sound": "The fact is that meaning is part and parcel of word-sound and word-utterance, as these ordinarily occur in reading and thinking" (164).

9 "It is a common myth that subvocalization - or more technically, covert speech behavior - retards reading proficiency. Some teachers have attempted to prevent subvocalization by taping lips or filling the mouths of pupils with marbles, by wrapping the tongue around a pencil and so forth. However, such efforts to inhibit subvocalization are futile, for the speech musculature still responds during silent reading even when so inhibited" (Corsini 258).

10 Total physical response is a pedagogic concept. Conceptualized by James Asher, the total physical response represents the interiorization through movement of a language first encountered outside the body (3-17).

11 Urbano uses this term to refer to Oreamuno's use of the second person to create interior monologue for her characters.

12 Gabriel promises repeatedly to look the word up but never does. This fact suggests and underscores the idea that the folkloric is displaced from the present. It is relegated to an archive constructed in the past and is accessible only in a future that, at least for Gabriel, doesn't exist.

\section{WORKS CITED}

ASher, JAmes J. "The Total Physical Response Approach to Second Language Learning." The Modern Language Journal 53.1 (1969): 3-17.

BERM Ú DEZ, MAN UEL. "Sergio Ramírez: Confesiones sobre Amanda." Semanario Universidad 15 Jun. 2015. N.p. 
B LANCO, JOHN D. Frontier Constitutions: Christianity and Colonial Empire in the

Nineteenth-Century Philippines. Berkeley: U of California P, 2009.

B ON I Lla, AB E LAR D o. "Yolanda Oreamuno." A lo largo del corto camino. Ed. Lilia

Ramos. San José: Editorial Costa Rica, 1961. 353-357.

Cas t a ̃̃ ón, Ad o l Fo. América sintaxis. México, D.F: Siglo XXI Editores, 2009.

CRA IG, HE RB ERT E. Marcel Proust and Spanish America: From Critical Response to

Narrative Dialogue. Lewisburg: Bucknell UP, 2002.

DE LA CAMPA, ROMÁ N. Latin Americanism. Minneapolis: U of Minnesota P, I999.

Do bles, fabín. "Defensa y realidad de una literatura." A lo largo del corto camino.

Ed. Lilia Ramos. San José: Editorial Costa Rica, I96I. 321 - 327.

G OLD, JANE T. "Feminine Space and the Discourse of Silence: Yolanda Oreamuno,

Elena Poniatowska, and Luisa Valenzuela." Eds. Noël M. Valis and Carol Maier.

In the Feminine Mode: Essays on Hispanic Women Writers. Lewisburg: Bucknell

UP, 1990. $195^{-203 .}$

—. "Yolanda Oreamuno." Rereading the Spanish American Essay: Translations of

I9th and 2oth Century Women's Essays. Austin: U of Texas P, 1995. 215 - 216.

GonZÁ LEZ, An n B. Sí pero no: Fabián Dobles and the Postcolonial Challenge.

Madison: Fairleigh Dickinson UP, 2005.

GonZÁLeZ, E CheVARRía R. Cuban Fiestas. New Haven: Yale UP, 20 Io.

HUEY, ED M UN D, B. The Psychology and Pedagogy of Reading: With a Review of the

History of Reading and Writing and of Methods, Texts, and Hygiene in Reading.

Cambridge: M.I.T. P, 1968.

MAÑACH, JORGE. Indagación del choteo. Barcelona: Linkgua Pensamiento, $201 \mathrm{I}$.

mARTínez S., Lu Z IVE T te. "Carmen Naranjo y la narrativa femenina en Costa Rica."

San José: Editorial Universitaria Centroamericana, 1987.

MC GUigan, F.J. “Cognitive Psychophysiology.” Ed. Raymond J. Corsini. Encyclopedia

of Psychology. New York: Wiley, I994. I87-I9I.

MENT ON, SEY M O UR. El cuento costarricense: estudio, antología y bibliografía.

Lawrence: U of Kansas P, 1964.

MORSE, RICHARD M. "The Multiverse of Latin American Identity." Ideas and

Ideologies in Twentieth Century Latin America. Ed. Leslie Bethell. New York:

Cambridge UP, I996. I-I29.

OREAMUNO, YOLAND A. “40o sobre cero.” A lo largo del corto camino. Ed. Lilia

Ramos. San José: Editorial Costa Rica, 196r. I37- I43.

—. "El ambiente tico y los mitos tropicales." A lo largo del corto camino. Ed. Lilia

Ramos. San José: Editorial Costa Rica, 1961. 15-27.

—. "Protesta contra el folklore." A lo largo del corto camino. Ed. Lilia Ramos. San

José: Editorial Costa Rica, 1961. 93-99.

—. La ruta de su evasión. San José: Editorial Universitaria Centroamericana, I970.

ramírez, Sergio. La fugitiva. Madrid: Alfaguara, 20 II. 
RAMOS, Lilia. "Sin noviciado, Yolanda Oreamuno escribe libros psicoanalíticos." Repertorio Americano 46 (1950): 185-188.

SCH M I T, CA RL. Political Theology: Four Chapters on the Concept of Sovereignty. Cambridge: MIT UP, 1985.

UR B AN O, VIC T O I A. Una escritora costarricense: Yolanda Oreamuno. Madrid: Ediciones Castilla de Oro, 1968. 